superior tracheostomy-to illustrate possible complications of classical tracheostomy. The necessity of very early surgico-plastic correction measures is emphasized, even in the presence of local infections.

Zusammenfassung. An Hand von vier Fällen mit primär ungünstig angelegten Tracheostomata - in drei Fällen lag eine Tracheostomia inferior, in einem Fall eine Tracheostomia superior vor - werden die möglichen Komplikationen der klassischen Tracheostomie dargestellt. Auf die Notwendigkeit möglichst frühzeitiger plastisch-chirurgischer Korrekturmaßnahmen auch bei bestehender lokaler Infektion wird hingewiesen.

\title{
156. Die Ernährung Bewußtloser
}

\author{
Ch. Lehmann-München
}

\section{The Feeding of Unconscious Patients in Neuro-Surgery}

Summary. The unconscious patients in neurosurgery-especially persons with a combined cranial brain injury -have a very high caloric requirement. For adults it amounts from 4000-5000 calories at least. In order to meet such a caloric requirement by parenteral feeding which is the minimum for a person suffering from brain injuries, at least you had to infuse $5000 \mathrm{cc}$ of liquid daily. This fails according to the following: 1 . The enormous quantity of liquid produces a considerable stress on the cardiovascular system. 2. Even if you infuse the fat simultaneously, it will take you that much time to infuse the remaining quantity of liquid that the serum concentration of the single substances becomes very high. The renal threshold is passed and most of the substances will no longer effect the metabolism. For that very reason we try to start early with a tube feeding. For a sufficient caloric intake you only need a quantity of liquid of $2500 \mathrm{cc}$. The tube feeding made in our diet kitchen is better tolerated than the industrial preparations.

Zusammenfassung. Bewußtlose Schwerkranke in der Neurochirurgie, insbesondere die Schädel-Hirnverletzten, haben einen sehr hohen Calorienbedarf. Er beträgt für Erwachsene mindestens 4000-5000 Calorien. Um einen solchen für einen Hirntraumatiker minimalen Calorienbedarf durch parenterale Ernährung zu decken, müßte man mindestens $5000 \mathrm{ml}$ Flüssigkeit pro Tag infundieren. Dieses scheitert aus folgenden Gründen: 1. Die hohe Flüssigkeitsmenge stellt eine erhebliche Kreislaufbelastung dar. 2. Selbst wenn man die Fette parallel einlaufen läßt, ist die Zeit für die Infusion der übrigen Flüssigkeitsmenge so groß, daß die Serumkonzentrationen der einzelnen Stoffe sehr hoch werden. Die Nierenschwelle wird überschritten und die Substanzen damit zum großen Teil nicht mehr stoffwechselwirksam. Wir versuchen daher, schon frühzeitig mit einer Sondennahrung zu beginnen. Dabei ist für eine ausreichende Calorienzufuhr nur eine Flüssigkeitsmenge von $2500 \mathrm{ml}$ notwendig. Die in unserer Diätküche hergestellte Sondennahrung zeichnet sich durch bessere Verträglichkeit gegenüber industriellen Präparaten aus. 